Primeros registros de leucismo en ocho especies

de mamíferos pequeños (Mammalia: Rodentia)

\title{
First records of leucism in eight species of small mammals (Mammalia: Rodentia)
}

\author{
Jorge Brito ${ }^{1}$ and Karla Valdivieso-Bermeo ${ }^{1,2 *}$
}

\begin{abstract}
${ }^{1}$ Museo Ecuatoriano de Ciencias Naturales del Instituto Nacional de Biodiversidad, División de Mastozoología. Calle Rumipamba 341 y Av. De Los Shyris. Casilla postal 17-07-8976. Quito, Ecuador. E-mail: jorgeyakuma@yahoo.es (JB).

1,2 Universidad Internacional del Ecuador, Escuela de Biología Aplicada. Km. 3 Av. Simón Bolívar. Casilla postal 17-21-1948. Quito, Ecuador. E-mail:kae_valdivieso@outlook.com (KVB).

* Corresponding author
\end{abstract}

Leucism is a partial hypopigmentary congenital disorder that indicates low levels of genetic diversity and is considered to be an unusual trait in wild populations. In continental America, few cases of abnormal coloration in vertebrates have been recorded. This feature can increase the selective pressure on individuals who have it, and can result from population isolation which, in turn, could act as an alarming indicator of environmental change. This condition has not been reported previously in genera of small rodent such as Akodon, Nephelomys, Thomasomys, Trasandinomys and Mesomys. Therefore, the aim of this note is to report 38 cases of leucism found in eight rodent species for the first time: Akodon mollis $(n=7)$, Nephelomys albigularis $(n=7)$, N. moerex $(n=18)$, Transandinomys talamancae $(n=2)$, Thomasomys auricularis $(n=1)$, T. taczanowskii $(n=1)$, T. paramorum $(n=1)$ and Mesomys hispidus $(n=1)$.

Key words: Ecuador; leucism; Rodentia.

El leucismo es un desorden hipopigmentario congénito, que refleja bajos niveles de diversidad genética y es considerado inusual en poblaciones silvestres. Pocos son los casos que han sido registrados de coloraciones anómalas en vertebrados para el continente americano. Esta característica puede incrementar la presión selectiva en los individuos que la presentan, pudiendo darse por aislamiento poblacional que a su vez podría actuar como un indicador de cambios ambientales. Esta condición nunca había sido reportada en los géneros de roedores pequeños: Akodon, Nephelomys, Thomasomys, Trasandinomys y Mesomys. Por lo tanto el objetivo de la presente nota es dar a conocer por primera vez 38 casos de leucismo para ocho especies de roedores: Akodon mollis $(n=7)$, Nephelomys albigularis $(n=7), N$. moerex $(n$ $=18)$, Transandinomys talamancae $(n=2)$, Thomasomys auricularis $(n=1)$, T. taczanowskii $(n=1)$, T. paramorum $(n=1)$ y Mesomys hispidus $(n=1)$.

๑ 2016 Asociación Mexicana de Mastozoología, www.mastozoologiamexicana.org

\section{Introduction}

Abnormal coloration in mammals and other animals is considered as a hypopigmentary congenital disorder that reflects low genetic diversity levels; these chromatic aberrations are expressed mainly as albinism and leucism (Phillips 1954; Bensch et al. 2000). Leucism is expressed as the almost total decoloration of certain parts of the body, but preserving the typical color of eyes, nails and skin (Bensch et al. 2000; Miller 2005). The occurrence of leucism is associated with factors such as pollution, environmental alterations (Moller and Mousseau 2001), low-quality diet (Owen and Shimmings 1992; Peles et al. 1995), or follicular damage (Phillips 1954; Hafner and Hafner 1987). Individuals with leucism are more frequent in small and isolated populations due to inbreeding, which causes recessive alleles to be expressed (Holyoak 1978; Bensch et al. 2000).

Leucism is relatively rare in small mammals (Steen and Sonerud 2012), with only 18 cases of abnormal colorations reported in the American continent for the order Rodentia (Appendix 1). In South America, the genera Akodon, Nephelomys and Thomasomys, all of which include a wide variety 
of species, as well as Trasandinomys and Mesomys, with fewer species, are taxa for which albinism and leucism in wild specimens have not been previously reported.

In Ecuador only two cases of color aberrations in small mammals are known, one albine Vampyrum spectrum specimen (Brito and Leon 2014) and one Carollia perpicillata specimen with leucism (Boada and Tirira 2010); information on these conditions for other mammals is unknown. This note reports the first cases of leucism for several species of Ecuadorian rodents distributed mainly to the southwest and other areas of the country.

\section{Materials and Methods}

The study included several field trips to eight sites in 2015. The study area comprises the Cordillera de Chilla, southeastern Ecuador, between $2,434 \mathrm{~m}\left(-79.501^{\circ} \mathrm{W},-3.625^{\circ} \mathrm{S}\right)$ and $3,668 \mathrm{~m}\left(-79.469^{\circ} \mathrm{W}\right.$, $\left.-3.063^{\circ} \mathrm{S}\right)$. The study sites include natural habitats with human interventions: montane forests (visually dominated by Polylepis sp, Ocotea sp and several Melastomataceae species); and moorland shrub (visually dominated by Stipa sp, Calamagrostis sp and several shrub species of Asteraceae). The field work was framed within the project "Guide to the mammals of the El Oro province".

The systematic methodology for capturing small mammals consisted in the use of live traps (Sherman and Tomahawk). One hundred traps (90 Sherman and 10 Tomahawk traps, the latter interspersed every two and three stations) were arranged in transects of 15 and 25 stations, each station with two and six traps, usually with a separation of approximately $10 \mathrm{~m}$ between stations. The trapping effort was 1,650 trap-nights. The bait used was a mixture of oats flavored with vanilla and coconut essence. The reference specimens are deposited in the Museo Ecuatoriano de Ciencias Naturales, Instituto Nacional de Biodiversidad (DMMECN). Additionally, a review of the mammal collection of DMMECN was conducted in search of specimens with this anomaly.

\section{Results}

A total of 170 rodent specimens belonging to 11 species were captured in Cordillera de Chilla. In all, nine individuals (5.3\%) had leucism (Figure 1 ). Thirty nine individuals of the genus Akodon were captured, six (15.4\%) of which showed leucism. In the case of Nephelomys and Thomasomys (with 27 and 57 specimens captured, respectively), two (7.1\%) and one (1.8\%) individuals showed this condition. All specimens were captured in areas with native vegetation.

As regards the revision of voucher specimens (DMMECN), 29 showed leucism (Table 1); these belong to two families, five genera and seven species. Cricetids (Figure 2) of the genus Nephelomys $(n=23)$ accounted for most cases, while Akodon $(n=1)$, Transandinomys $(n=2)$, Thomasomys $(n=$ $2)$, and Mesomys ( $n=1)$ exhibited leucism to a lesser extent.

The sum of leucism records in Cordillera de Chilla plus the voucher specimens amounts to 38 individuals of eight species: Akodon mollis $(n=7)$, Nephelomys albigularis $(n=7)$, N. moerex $(n=$ 18), Transandinomys talamancae $(n=2)$, Thomasomys auricularis $(n=1), T$. taczanowskii $(n=1), T$. paramorum $(n=1)$, and Mesomys hispidus $(n=1)$.

\section{Discussion}

In southwestern Ecuador, Cordillera de Chilla is considered as an important bridge for the passage of wild animals between the Pacific slope, the Andes and the Amazon (Krabbe 2008); however, in the last decades natural habitats have been fragmented, with forests and moors being replaced by pasture and large areas of pine plantations. Today there are only small isolated remnants along the borders of ravines and rocky walls. Even the small ravine forests still existing are being disturbed by livestock that invades these areas to feed on herbs and tree bark. This situation is likely influencing the emergence of species with leucism, in agreement with Holyoak (1978), Bensch et al. (2000) and Lopucki and Mróz (2010), who state that the frequency of occurrence 


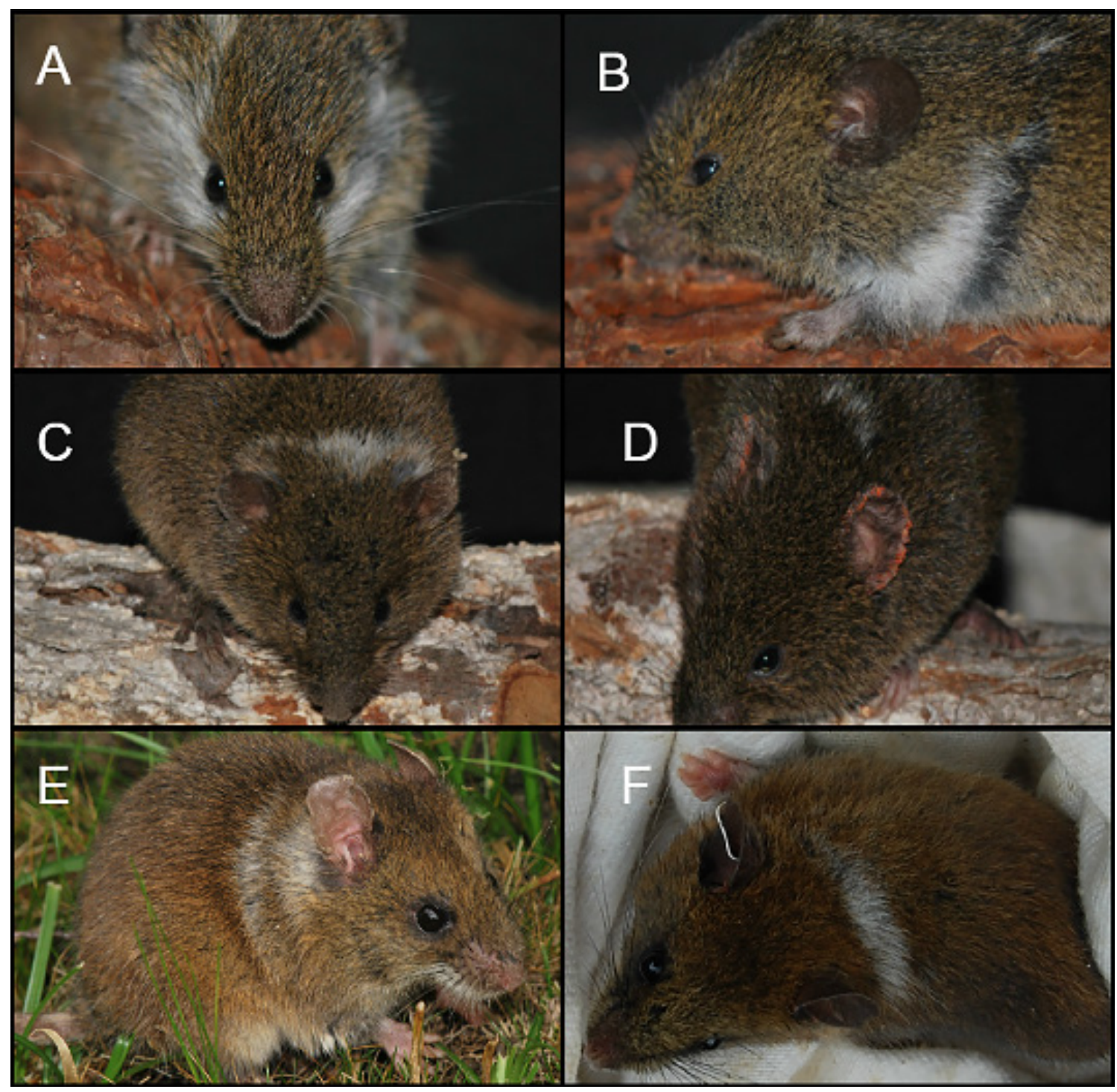

Figure 1. Rodents with leucism recorded in Cordillera de Chilla, southwestern Ecuador: $A=$ Akodon mollis (DMMECN 4,847); $\mathrm{B}=$ A. mollis (DMMECN 4,849); $\mathrm{C}=$ A. mollis (DMMECN 4,833); $\mathrm{D}=$ A. mollis (DMMECN 4,845); $\mathrm{E}=$ Thomasomys taczanowskii (DMMEC 4,822); Polylepis forest in northern Ecuador: $\mathrm{F}=$ Thomasomys paramorum (not collected). Photographs J. Brito.

of Individuals with atypical colorations in a wild population is affected mainly by the isolation of populations.

The fragmentation of natural habitats in Cordillera de Chilla could be preventing gene flow between rodent populations, even in Akodon mollis, a terrestrial species that inhabits forests and moorland shrub, and which is usually tolerant to habitat modification. However, N. albigularis, a terrestrial rodent, and T. taczanowskii a rodent of semi-arboreal habits, both associated only with forests, also showed leucism, although in smaller numbers.

The present is the first report of leucism in eight rodent species of Ecuador. The museological reviews, field reports and studies on population genetics will contribute to understand the existence of spatial and temporal patterns, or demonstrate the indirect causes of these aberrations in natural populations.

\section{Acknowledgments}

We thank the Provincial Autonomous Government of El Oro for funding the project "Guide to the Mammals of El Oro province". Thanks also to R. Garcia, J. Curay, M. Noboa, A. Pilatasig, R. Bravo, 
C. Garzón, G. Pozo and H. Román for their support in field work. The study was conducted under a scientific authorization granted by the Ministry of the Environment of El Oro, N ${ }^{\circ} 005-I C-F L O-$ FAU-DPAEO-MAE. This manuscript was translated by Maria Elena Sánchez Salazar with support of THERYA through a CONACYT grant.

Table 1. Localities of Ecuadorian rodents with leucism reported in this contribution.

\begin{tabular}{|c|c|c|c|c|c|}
\hline Species & Province/Locality & Long. & Lat. & Alt. & Voucher (DMMECN) \\
\hline \multirow[t]{5}{*}{ Akodon mollis } & Azuay, El Cajas & -79.0872 & -3.1797 & 4,000 & 0077 \\
\hline & El Oro, Cerro de Arcos & -79.4694 & -3.0630 & 3,668 & $4726-27$ \\
\hline & El Oro, Payana & -79.6152 & -3.5044 & 3,044 & 4833 \\
\hline & El Oro, Shiñinguro & -79.5933 & -3.4777 & 3,178 & $4845,4847,4849$ \\
\hline & Imbabura, Cotacachi & -78.6677 & 0.3108 & 1,756 & 3420 \\
\hline \multirow[t]{6}{*}{ Nephelomys albigularis } & El Oro, Chivatuco & -79.5011 & -3.625 & 2,434 & 4847 \\
\hline & El Oro, Yacuviñay & -79.7113 & -3.5749 & 2,473 & 4903 \\
\hline & Morona Santiago, Parque Nacional & -78.4968 & -2.1898 & 3,300 & 1521 \\
\hline & Sangay & & & & \\
\hline & Pichincha, Calacalí & -78.5354 & 0.0030 & 2,240 & 3524,3528 \\
\hline & Pichincha, Nanegalito & -78.7005 & 0.0628 & 1,740 & 2525 \\
\hline \multirow[t]{6}{*}{ Nephelomys moerex } & Cotopaxi, San Francisco de las Pampas & -79.0051 & 0.4179 & 2,050 & 1085 \\
\hline & Pichincha, Calacalí & -78.5354 & 0.0030 & 2,240 & 2545 \\
\hline & Pichincha, Lloa & -78.5836 & -0.2497 & 3,387 & $2551,2725-26,2739,2733,2737$ \\
\hline & Pichincha, Nanegalito & -78.7005 & 0.0628 & 1,740 & $2816,2824,28262846,4397$ \\
\hline & Pichincha, Nono & -78.6678 & -0.1329 & 2,800 & $2484,2538-39,2541$ \\
\hline & Pichincha, Reserva Pahuma & -78.7005 & 0.0628 & 1,740 & 2482 \\
\hline Transandinomys talamacae & Pichincha, Minas, & -78.4343 & 0.1670 & 1,820 & $2583-84$ \\
\hline Thomasomys auricularis & Azuay, El Cajas & -79.2355 & -2.7872 & 4,000 & 0071 \\
\hline Thomasomys taczanowskii & El Oro, Chilla Cocha & -79.6252 & -3.5005 & 3,315 & 4822 \\
\hline Thomasomys paramorum & Carchi, Bosque de Polylepis & -77.0052 & 0.2309 & 3,650 & Not collected \\
\hline Mesomys hispidus & $\begin{array}{l}\text { Sucumbíos, Reserva Ecológica Cofán- } \\
\text { Bermejo }\end{array}$ & -77.9822 & 0.7154 & 375 & 3486 \\
\hline
\end{tabular}

\section{Literature cited}

Bensch, S. B., Hansson, D. Hasselquist, and B. Nielsen. 2000. Partial albinism in a semi-isolated population of Great Reed Warblers. Hereditas 133:167-170.

Benton, A. 1953. An unusual concentration of albino muskrats. Journal of Mammalogy 34:262.

Boada, C., AND D. G. TiriRa. 2010. First record of partial albinism (leucism) in Carollia perspicillata (Phyllostomidae) in Ecuador. Chiroptera Neotropical 16:755-766.

Bowman, J., and R. M. Curran. 2000. Partial albinism in the red-backed vole, Clethrionomys gapperi, from New Brunswick. Northeastern Naturalist 7:181-182.

Brito, J., AND C. León. 2014. Primer caso de albinismo en Vampyrum spectrum (Chiroptera: Phyllostomidae) para Ecuador. Mammalogy Notes 1:14-15.

Burnet, W. L. 1925. Dichromatism and albinism in Thomomys clusius. Journal of Mammalogy 6:129.

Cademartori, C. V., and S. M. Pacheco. 1999. Registro de albinismo em Delomys dorsalis (Hensel, 1872) (Cricetidae, Sigmodontinae). Biociencias 7:195-197. 


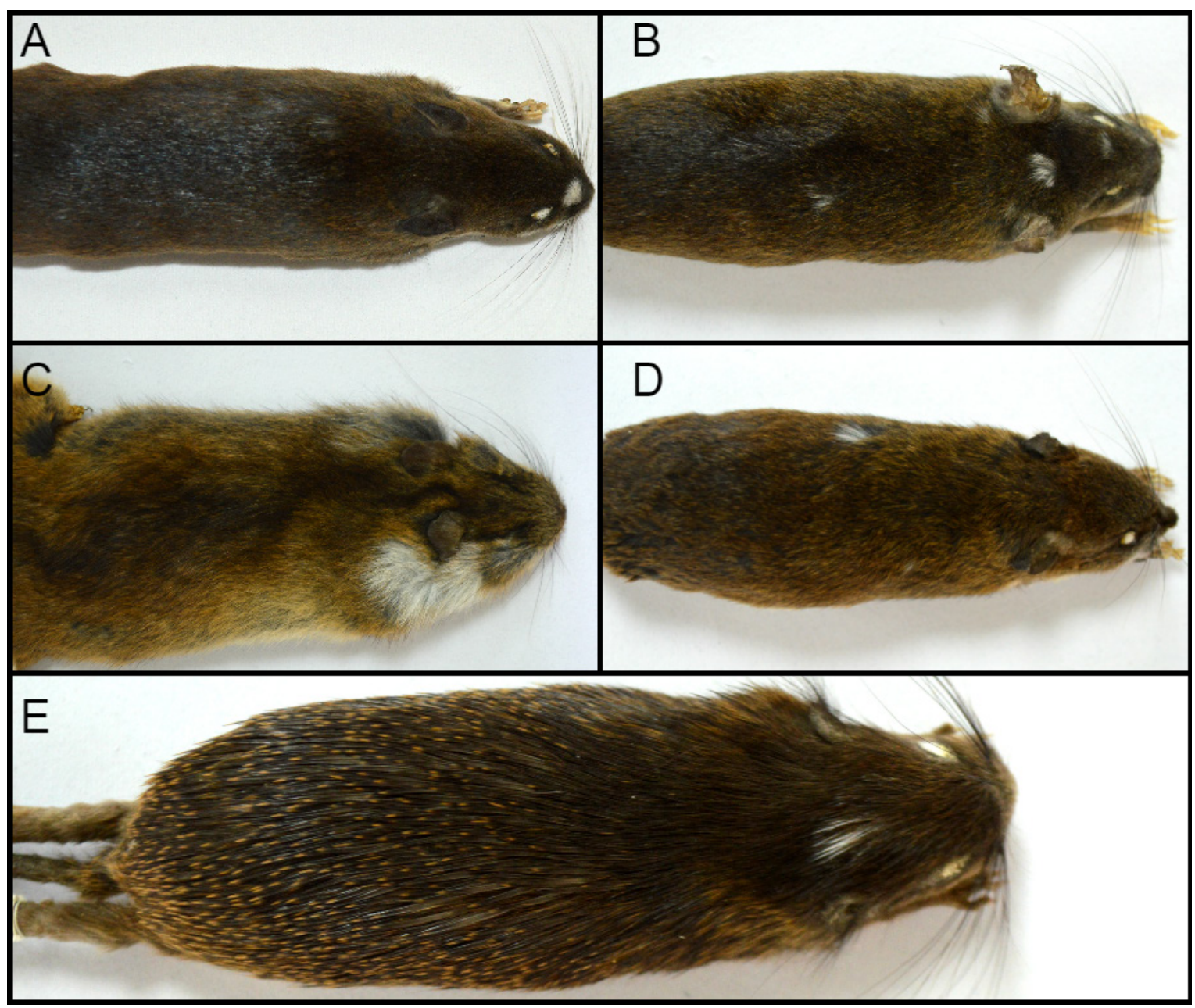

Figure 2. Voucher specimens with leucism: $A=$ Nephelomys albigularis (DMMECN 3,624), $B=N$ moerex (DMMECN 2,824), $C=$ Thomasomys auricularis (DMMECN 71), $\mathrm{D}=$ Transandinomys talamacae (DMMECN 2,584) and $\mathrm{E}=$ Mesomys hispidus (DMMECN 3,486). Photographs K. Valdivieso-Bermeo.

Camargo, I., E, Ríos, C. Cornejo-Latorre, and S. T. Álvarez-Castañeda. 2014. First Record of Leucism in the Genus Peromyscus (Mammalia: Rodentia). Western North American Naturalist 74:366-368.

Egoscue, H. J. 1958. Albinism in the western harvest mouse. Journal of Mammalogy 39:306.

Egoscue, H.J., AND T. J. Lewis. 1968. An albino long-tailed pocket mouse from Utah. Journal of Mammalogy 49:319.

GuILEs, C. 1997. Sightings of albino, or albinistic, chipmunks. Northeastern Naturalist 4:47-49.

Hafner, M., And D. Hafner. 1987. Geographic distribution of two Costa Rican species of Orthogeomys, with comments on dorsal pelage marking in the Geomyidae. Southwestern Naturalist 32:5-11.

Holyoak, D. T. 1978. Variable albinism of the flight feathers as an adaptation of recognition of individual birds in some Polynesian populations of Acrocephalus warblers. Ardea 66:112-117.

JanNetT, F. J., JR. 1981. Albinism and its inheritance in populations of the montane vole. Journal of Heredity 72: 144-146.

KrabBe, N. 2008. Arid valleys as dispersal barriers to high-Andean forest birds in Ecuador. Cotinga, 29:28-30.

LopUCKI, R., AND I. Mróz. 2010. Cases of colouration anomalies in small mammals of Poland and reasons for their incidence. Annales UMCS, Biologia 65:67-76.

Martínez, C. M., R. Bautista and M. Verona. 2013. Albinismo platinado en Liomys pictus (Mammalia: Heteromyidae). Therya 4:641-645

Miller, J. D. 2005. All about albinism. Missouri Conservationist 66:5-7.

Moller, A. P., And T. A. Mousseau. 2001. Albinism and phenotype of Barn Swallows. Evolution 55:2097-2104.

NeaL, B. 1964. Albino Harris ground squirrels at Ohio, Arizona. Southwestern Naturalist 9:104-105. 
Oliveira, S. V. 2009. Albinismo parcial em cutia Dasyprocta azarae (Lichtenstein, 1823) Rodentia, Dasyproctidae, no sul do Brasil. Biotemas 22:243-246.

Owen, M., And P. Shimmings. 1992. The occurrence and performance of leucistic Barnacle Geese, Branta leucopsis. Ibis 134:22-26.

Parsons, G. J., and S, Bondrup-Nielsen. 1995. Partial albinism in an island population of meadow voles, Microtus pennsylvanicus, from Nova Scotia. Canadian Field-Naturalist 109:263-264.

Peles, J. D., M. F. Lucas, And G. W. Barrett. 1995. Population dynamics of agouti and albino meadow voles in high-quality, grassland habitats. Journal of Mammalogy 76:1013-1019.

PessôA, A. L., And S. F. Rels. 1995. Coat color variation in Proechimys albispinus (Geoffroy, 1838) (Rodentia, Echimyidae). Boletim do Museu Nacional, Nova Série Zoologia 361:1-5.

Phillips, A. R. 1954. The cause of partial albinism in a Great-tailed Grackle. Wilson Bulletin 66:66.

Ramirez, O. E., and M. Arana. 2005. Albinism in the Andean leaf-eared mouse, Phyllotis andium (Rodentia, Cricetidae). Mastozoología Neotropical 12:269-270.

Schantz, V. S. 1960. Record of an albino pine vole. Journal of Mammalogy 41:129.

Steen, R., And G. A. Sonerud. 2012. A bank vole (Myodes glareolus) with complete leucismo captured by a Eurasian kestrel (Falco tinnunculus) in Norway. Annales Zoologici Fennici 49:306-308.

TuRkowski, F. J., AND W. S. Parker. 1967. Albino round-tailed ground squirrel in Arizona. Southwestern Naturalist 12:197-198.

Whitman, J. S. 2009. Complete albinism in a Northern Red-backed Vole, Myodes rutilus, in Alaska. Canadian Field Naturalist 123:167-168.

Submitted: May 19, 2016

Reviewed: August 19, 2016

Accepted:September 7, 2016

Associated editor: Lia Méndez 


\section{Appendix 1}

Records of rodents with chromatic aberrations in the American continent.

\begin{tabular}{|c|c|c|c|}
\hline Rodentia & Country & Condition & Source \\
\hline \multicolumn{4}{|l|}{ Sciuridae } \\
\hline Ammospermophilus harrisii & USA & Albinism & Neal 1964 \\
\hline Citellus sp & USA & Albinism & Turkowski y Parker 1967 \\
\hline Tamias striatus & USA & Albinism & Guiles 1997 \\
\hline \multicolumn{4}{|l|}{ Geomyidae } \\
\hline Thomomys sp & USA & Albinism and Leucism & Burnet 1925 \\
\hline \multicolumn{4}{|l|}{ Heteromidae } \\
\hline Liomys pictus & Mexico & Albinism & Martínez-Colonel et al. 2013 \\
\hline Perognathus sp & USA & Albinism & Egoscue and Lewis 1968 \\
\hline \multicolumn{4}{|l|}{ Cricetidae } \\
\hline Akodon mollis & Ecuador & Leucism & This study \\
\hline Clethrionomys gapperi & Canada & Leucism & Bowman and Curran 2000 \\
\hline Delomys dorsalis & Brazil & Albinism & Cademartori and Pacheco 1999 \\
\hline Microtus montanus & USA & Albinism & Jannett 1981 \\
\hline Microtus pennsylvanicus & USA & Albinism and Leucism & Peles et al. 1995; Parsons and Bondrup-Nielsen 1995 \\
\hline Microtus pinetorum & USA & Albinism & Schantz 1960 \\
\hline Myodes rutilus & USA & Albinism & Whitman and Jackson 2009 \\
\hline Nephelomys albigularis & Ecuador & Leucism & This study \\
\hline Nephelomys moerex & Ecuador & Leucism & This study \\
\hline Ondatra zibethicus & USA & Albinism & Benton 1953 \\
\hline Peromyscus fraterculus & Mexico & Leucism & Camargo et al. 2014 \\
\hline Phyllotis andium & Peru & Albinism & Ramirez and Arana 2005 \\
\hline Reithrodontomys megalotis & USA & Albinism & Egoscue 1958 \\
\hline Thomasomys auricularis & Ecuador & Leucism & This study \\
\hline Thomasomys paramorum & Ecuador & Leucism & This study \\
\hline Thomasomys taczanowskii & Ecuador & Leucism & This study \\
\hline Transandinomys talamancae & Ecuador & Leucism & This study \\
\hline \multicolumn{4}{|l|}{ Dasyproctidae } \\
\hline Dasyprocta azarae & Brasil & Leucism & Oliveira 2009 \\
\hline \multicolumn{4}{|l|}{ Echimyidae } \\
\hline Mesomys hispidus & Ecuador & Leucism & This study \\
\hline Trinomys albispinus & Brasil & Leucism & Pessôa and Reis 1995 \\
\hline
\end{tabular}


490 THERYA Vol.7 (3): 483-489 